„Bohemistyka” 2021, nr 3, ISSN 1642-9893

Lubomír HAMPL

DOI: $10.14746 /$ bo.2021.3.7

Uniwersytet Śląski w Katowicach

\section{Koronawirus zmienia język czeski - powstawanie nowych leksemów}

Keywords: Czech language, neologisms and neosemantisms, new vocabulary, coronavirus, masks, remote learning, lexical adhesions, formants, word formation, composite, crown-, hybrid formation and lexical traces, semantic field

Słowa kluczowe: język czeski, neologizmy i neosemantyzmy, nowe słownictwo, koronawirus, maseczki, nauczanie zdalne, zrosty leksykalne, formanty, słowotwórstwo, złożenie, człon korona-, formacja hybrydalna i kalk leksykalne, pole semantyczne

\section{Abstract}

The article focuses on newly emerging Czech words (see neologisms and neosemantisms). The reasons for the formation of such lexemes were given and their importance was selectively emphasized. Several examples of creating new lexical and tance was selectively emphasized. Several examples of creating new lexical and
word-formation structures were cited, and problematic linguistic connections from the point of view of political correctness were also specified. New lexical adhesions were narrowed down mainly with the prefix korona-, but also words profiling other artifacts or activities were quoted: Czech rouška - English mask, Czech distanční vzdélávánívýuka - English distance learning, Czech společenský odestup/rozestup English social distance, Czech eRecept - English e-prescription. etc. Some of these newly created names are experiencing a real renaissance due to the much higher attendance as they have shifted from the periphery towards the center of the language.

W artykule skoncentrowano się na nowo powstających słowach w języku czeskim (patrz neologizmy i neosemantyzmy). Podano przyczyny powstawania takich leksemów oraz zwrócono wybiórczo uwagę na ich znaczenie. Przywołano parę przykładów tworzenia nowych tworów leksykalnych i słowotwórczych oraz wyszczególniono także problematyczne połączenia językowe z punktu widzenia poprawności politycznej. Skupiono się na nowych zrostach leksykalnych głównie z przedrostkiem korona-, ale także przywoływano słowa profilujace inne artefakty lub czynności: czes. rouška - pol. maseczka, czes. distanční vzdélávání/výuka - pol. nauczanie zdalne, czes. společenský odestup/rozestup - pol. dystans społeczny, czes.
eRecept - pol. e-recepta. itp. Niektóre z tych nowo powstałych nazw przeżywają prawdziwy renesans ze względu na zdecydowanie większą frekwencję, ponieważ przesunęły się z peryferii w kierunku centrum języka.

\section{Wprowadzenie}

Według niedawno rozpoczetych i cały czas nieustannie przeprowadzanych badań naukowych w Republice Czeskiej (por. np. bazę danych Neomat ${ }^{1}$ lub inne strony wirtualne ${ }^{2}$ dostępne on-line), powstały już dziesiątki, ba nawet setki nowych słów, które jednak nie są neologizmami, na co zwracają uwagę lingwiści. Przybierają one postać neosemantyzmów ${ }^{3}$.

Przy obserwacji procesów ne ose mantyzacji leksykalnej spotykamy się z sytuacją, że niektóre jednostki leksykalne znacze-

${ }^{1}$ We współczesnym języku czeskim na przestrzeni nadzwyczajnej sytuacji epidemiologicznej powstało prawie 500 nowych słów o różnej frekwencji (przypuszcza się, że w bliskiej przyszłości - jak sytuacja się nie poprawi - będzie ich jeszcze więcej), w których najczęściej wyprofilowany jest leksem korona w różnorodnie możliwych kombinacjach, wariantach i formach leksykalnych, uwzględniajac oprócz „bazowej” podstawy słowotwórczej dodatkowo przedrostki, przyrostki, końcówki fleksyjne, zrosty, uniwerbizację i multiwerbizację, zapożyczenia (egzotyzację) i przykłady rodzimego zadomowienia (domestykację) itp. (por. http://www.neologismy.cz/index.php?retezec=korona\%2A\&prijimam=1\&stranka=4\&heslar=1).

${ }^{2}$ Powstaje również inny wirtualny rejestr, por. https://cestina20.cz/slovnik/ oraz Český národní korpus https://www.korpus.cz/slovo-v-kostce/search/cs/koronavirus.

${ }^{3}$ Inaczej neologizm znaczeniowy. Jest to wyraz/wyrażenie użyte w nowym znaczeniu. Neosemantyzmy powstają wtedy, gdy istnieje potrzeba nazwania nowych rzeczy, zjawisk, nieznanych wcześniej, dla których nie mieliśmy odpowiedniego słowa. Neosemantyzmy są więc jednym ze sposobów wzbogacania słownictwa (por. Janowska, Niewiara 2001, s. 128). Czeska szkoła zaś podkreśla, że „n e o s é m a n t i s m u s to neologismus vznikající posunem původního významu (rozšíření nebo specializace významu), tzv. sémantický neologismus" (Lotko 2003, s. 78). Z punktu widzenia kryterium strukturalnego do neologizmów zaliczane są również neosemantyzmy, jako jednosłowne jednostki (por. Martincová 1998, s. 14). Takie neosemantyzmy są to „slova s novým významem/významy” (Martincová 2004, s. 19), traktowane jako połączenie istniejącej starej formy i nowego znaczenia (por. Rangelova 2005, s. 159). Mamy również do czynienia z określeniem sémantický novotvar 
niowo rozwijają się w relacji z obcojęzycznym środowiskiem, por. kalki i formacje hybrydalne 4 . Źródłem przejmowania nowych wyrazów czy znaczeń leksykalnych w języku czeskim jest przede wszystkim angielszczyzna, która współcześnie jest dominującym środkiem komunikacji międzynarodowej. Procesy neosemantyzacyjne powstałe w wyniku wpływu języka obcego dotyczą przede wszystkim tych leksemów, które mają ponadnarodowy charakter (por. grekę i łacinę). Czasami są oznaczane terminem europeizmy (por. Mravinacová 2005, s. 180). Obserwowane przez nas neosemantyzmy w języku czeskim to typowe kalki (Svobodová 2009, s. 39-41 i 101).

W przeciągu niespełna roku powstały takie słowa, jak: koronakrize, koronténa, koronapacient, koronapa(á)rty, koronakalendár, koronasvátky, koronaprázdniny, koronadovolená, koronanákup, koronarekord, koronapozitivní, koronavirusák, koronatest, koronaúmrtí, koronapsychóza, koronarecese, koronatrend, koronáč. Ze względu na ramy objętościowe niniejszego tekstu wyszczególnić i opisać można wyłącznie niektóre spośród nowych słów, które pojawiły się ostatnimi czasy w języku czeskim w związku z bezpośrednią reakcją na wydarzenia spowodowane aktualna sytuacja dotyczaca pandemii koronawirusowej. Według Michaeli Liškovej z Instytutu Języka Czeskiego Akademii Nauk Republiki Czeskiej (Ústav pro jazyk český Akademie věd České republiky), która zajmuje się badaniem i analizą językową neologizmów, w języku czeskim powstało sporo nowych słów

(Kraus 2007, s. 551). Przeprowadzane analizy różnorodnych przykładów językowych - jak zaznacza Cierpich-Kozieł (2020, s. 104) - prowadzą do wniosku, że zasób leksykalny polszczyzny (ale i innych języków - uwagi własne L.H.) wzbogacił się o wspomniany neosemantyzm korona, który występuje w znaczeniach: 1) 'nowy wirus, koronawirus'; 2) 'czasy koronawirusa, okres pandemii'. W znaczeniu drugim mamy do czynienia $z$ uniwerbizacją, której skutkiem jest zmiana semantyczna polskiego rzeczownika korona.

${ }^{4}$ Dotyczy to formacji mających charakter hybrydalny, czyli chodzi zarówno o derywaty proste, jak i struktury złożeniowe oraz różnorodne konstrukcje składniowe (kilkuwyrazowe), których elementy pochodzą najcześciej z odmiennych języków. Słownictwo hybrydowe odznacza się nie tylko ciekawą strukturą formalną, ale i etymologią, semantyką i pragmatyką językową. mających bezpośredni związek z epidemią koronawirusa. Przykłady te rejestrowane są w bazie danych Neomat i gromadzone przez Zakład Współczesnej Leksykologii i Leksykografii (Oddělení současné lexikologie a lexikografie).

Zebrany materiał w bazie Instytutu podlega daleszemu opisowi, aby społeczeństwo miało szerszy ogląd korespondujący z aktualną sytuacją językową i aby można było lepiej zrozumieć metaforycznometonimiczne znaczenie nowo powstałych słów, ich właściwą symbolikę, odpowiednią konotację, zhierarchizowane wartościowanie, semantykę zrostów leksykalnych, a także aby użytkownicy mogli się zabawić niektórymi sztucznymi formacjami wyekscerpowanymi ze stron internetowych, tym samym Intytut zwraca uwage na zabawny charakter języka. Często właśnie za pomocą żartów językowych, eufemizmów obchodzimy czy łagodzimy tabu, ,rozbrajamy” trudną rzeczywistość, co jest w zgodzie z charakterem narodowym Czechów. Jak mówi przysłowie: jiný kraj, jiný mrav - co kraj, to obyczaj.

We wspomnianej bazie danych Neomat umieszczane są cały czas słowa, związane z epidemią koronawirusa rozpoczynające się bądź na literę $k$, tj. korona (pożyczka adaptowana), albo rozpoczynające się na literę $c$, czyli corona (pożyczka-cytat) ${ }^{5}$. „Takich wyrazów jest już dużo, a będzie ich w przyszłości jeszcze więcej ${ }^{6}$, ponieważ do bazy danych stopniowo będą dopisywane nowe użycia, jakie odnotowano w komunikacji językowej”, a zwłaszcza w języku mówionym i pisanym, czyli w prasie, telewizji, radiu, ale także na forach internetowych, Facebooku, Instagramie i wielu innych wirtualnych portalach - zaznaczyła Lišková.

${ }^{5}$ Por. dubletywno-wariantywny zapis graficzny, który jednak nie jest jeszcze skodyfikowany w czeskich Pravidlach českého pravopisu.

${ }^{6}$ Niektóre naturalnie wyjda z użycia i stopniowo zanikna, podobnie jak to było dawniej: mnóstwo różnych leksemów rozpoczynających się od czeskiej „předpony nebo první části složených slov" (por. Martincová 2004, s. 20), jak np.: euro-, eko-, bio-, de-, re-, anti-, ultra- czy neo- zanikło. Współcześnie mamy do czynienia z popularnością przedrostka korona-, obecnego np. w wielu nowo powstałych słowach trzeciej dekady XXI wieku. 


\section{Język czeski versus korona}

Według czeskiej lingwistki, Michaeli Liškovej, dzisiaj już nikogo nie zaskoczą takie wyrazy, jak: koronakáza [dosł. pol. korona zakażenie], koronaepidemie, koronakrize, koronadeprese, koronapanika, koronamánie, koronašok, koronténa 'karanténa kvůli koronaviru' (kwarantanna spowodowana przez koronawirus) czy koronáč ('koronawirus'). Aktualną problematykę ujmują również (nominalne i werbalne) połączenia słowne, które jednak w określonych sytuacjach nie zawierają pierwszej części korona. Można tutaj przywołać np. nowo powstałą jednostkę językową škola v pyžamu 'sposób nauki na odległość ${ }^{7}$, kiedy zamknięto szkoły z powodu szerzenia się lub rozprzestrzeniania się koronawirusa'.

O bogatej kreatywności w języku czeskim świadczy tworzenie różnych nowych tworów leksykalnych i słowotwórczych z jednakowym znaczeniem. Odnotowano np. synonimiczne wyrazy dla człowieka, który w czasie trwania pandemicznej sytuacji zachowuje się nie tylko nieodpowiednio, ale przede wszystkim nieodpowiedzialnie, z powodu tego, że nie nosi ochronnej maseczki. Używane są takie określenia, jak: koronaidiot lub covidiot. Warto zwrócić także uwagę na fakt, że wśród nowych słów znajdują się również takie wyrażenia, które, biorąc pod uwagę ekspresję słowną, są trudne do szybkiej realizacji ustnej, a tym samym realizacji owej ekspresji, np.: koronapokalypsa (podwójny zrost leksykalny) czy koronagrilsezona (potrójny zrost).

Pojawiają się także połączenia językowe, które są problematyczne z punktu wiedzenia poprawności politycznej. Dotyczy to np. oznaczenia choroby COVID-19 jako chińskiej grypy - čínská chripka. Odsyła to nas do rzeczywistości, w której zachorowanie spowodowane nowym koronawirusem (infekcją) pojawiło się pierwszy raz pod koniec 2019 roku właśnie w Chinach, w miejscowości Wuhan.

${ }^{7}$ Chodzi o bezpieczne dla wszystkich nauczanie (zwłaszcza z punktu widzenia zdrowia), by potencjonalnie chora osoba nie zarażała wirusem innych.
Neologizmy często powstają pod wpływem ważnych wydarzeń społecznych. Taką ważną kwestią jest dążenie do pofolgowania sobie w czasie pandemii w psychicznie trudnej sytuacji lub poluzowania samemu obowizujących obostrzeń. Zauważono, że np. w komunikacji nieformalnej w sieciach społecznościowych pojawiają się współcześnie przede wszystkim nieliterackie wyrażenia, zabawne słowa oraz leksemy należące do sfery wulgaryzacji językowej.

Jakie więc powstają nowe słowa $\mathrm{w}$ trakcie trwania pandemii?

Są to najczęściej zrosty leksykalne (z reguły dwóch rzeczowników) o następującej strukturze: słowem „bazowym” jest leksem korona, do którego dołączony jest element informujący o cesze człowieka lub charakterze zjawiska związanego z pandemią, np.:

- koronafob ${ }^{8}$ 'określenie człowieka, który przestrzega wszystkich ustalonych obostrzeń z powodu strachu przed zakażeniem się koronawirusem, a czasami nawet $\mathrm{z}$ tego powodu też panikuje', 'osoba panicznie bojąca się koronawirusa';

- koronadeprese 'depresja człowieka spowodowana koronawirusem';

- koronaskeptik 'określenie człowieka, który twierdzi, że koronawirus nie różni się od zwykłej grypy';

- koronamóda 'specyficzny styl ubierania się podczas przebywania w domu np. w czasie kwarantanny'; najczęściej jest to: dres sportowy, duży podkoszulek i papcie - czyli luźne „domowe” ubranie;

- koronavánoce/koronavelikonoce - 'Święta Bożego Narodzenia lub Wielkanocy spędzane w czasie pandemii bez krewnych i przyjaciół’.

\footnotetext{
${ }^{8}$ Ponieważ wiemy, że choroba ta powstała w Chinach, w języku czeskim wiẹkszą frekwencję odnotowano w użyciu zrostu činofob 'strach przed chińskimi produktami', gdzie konceptualizowana domena A została przeniesiona pojęciowo na domene B, dotyczaca choroby, por. 'strach przed koranawirusem'. Przywołać także można nowo powstały zrost koronarasismus 'uprzedzenie do obywateli, pochodzących z państw, gdzie jest największa liczba zachorowań (Chiny, Włochy, Indie)'. Zaobserwowano przesunięcie metonimiczne čínská rýmička (dosł. chiński katarek), które często wiąże się $\mathrm{z}$ zaobserwowana ironią. Znane jest także określenie wuchanvir, czyli wirus pochodzący z miejscowości Wuchan.
} 
Inne leksemy mają podstawę słowotwórczą koron- + czeski sufiks. Powstaje wtedy typowy czeski wyraz ${ }^{9}$, z zerową końcówką fleksyjną, np.: koronáč 'choroba koronawirus', 'człowiek zarażony koronawirusem, ${ }^{10}$, lub koroňák 'koronawirus o nazwie SARS-CoV-2'.

Niektóre wyrazy złożone w języku czeskim zachowują pierwotną grafię pierwszego członu, $\mathrm{np}$.:

- coronapanika 'chaos, panika powstała z powodu pandemii, wówczas obserwujemy irracjonalne zachowanie niektórych ludzi,'

- coronanarozeniny 'urodziny spedzone w samotności z powodu kwarantanny lub chorowania na koronawirusa'.

Powstają również konstrukcje adiektywno-substantywne, co jest zgodne z czeską normą i kodyfikacją językową, wówczas przymiotnik znajduje się przed rzeczownikiem, np:

- koronavirová opona - [dosł. kurtyna koronawirusowa] 'zamknięcie granic państwa i ograniczenie ruchu przygranicznego'. Leksem kurtyna w byłej Czechosłowacji do 1989 roku miał negatywne konotacje, czyli do rewolucji aksamitnej, kiedy nie można było swobodnie podróżować za granicę, por. czes. železná opona - pol. żelazna kurtyna;

- koronovační klenoty - [fonetycznie bliskie podobieństwo z wyrażeniem korunovační klenoty], w której występuje istotne porównanie alegoryczne: królewska korona i berło czy jabłko utożsamiane są z punktu widzenia funkcjonalności z maseczką i respiratorem, por. 'roušky a respirátory jako ochranné pomůcky před koronavirem (Covid-19)' - 'maseczki i respiratory jako pomoce ochronne przed koronawirusem (Covid-19)'

\footnotetext{
${ }^{9}$ Ze względu na fakt, że język czeski jest najbardziej fleksyjnym językiem
} spośród wszystkich języków Słowiańszczyzny, użytkownicy języka mogą sobie pozwolić na tego typu zabiegi językowe.

${ }^{10}$ Można także użyć konstrukcji (zrostu leksykalnego) koronavirusák 'pacjent z chińskim koronawirusem', 'pacjent zakażony/zarażony koronawirusem'.
Nie wszystkie jednak nowe słowa bazują na leksemie korona czy sa związane z terminem koronawirus. Niektóre wykorzystują czeski leksem rouška (pol. maska/maseczka), np.:

- rouškovnik' słup do wieszania maseczek za darmo';

- rouškobudka 'miejsce, w którym można bezpłatnie odebrać maseczkę', najczęściej w tzw. knihobudkách;

- rouškomat 'automat, w którym można kupić maseczkę', 'urzadzenie, w którym można nabyć maseczkę za określoną opłatą'.

Czesi z dużą dozą humoru podkreślają, że będą vařit rouškovou (analogicznie jak: gotować inne rodzaje zup, np. vařit rajčatovou, žampionovou, květákovou, houbovou, zeleninovou etc.) i tworzą neologizmy na bazie leksemu rouška z wykorzystaniem czeskich afiksów, np.:

- vařit rouškovou 'gotować maseczki we wrzątku, żeby je zdezynfekować';

- hrát rouškovanou 'nosić maseczkę' [dosł. grać w maseczkową grę];

- roušičky (šičky roušek) 'osoby szyjące maseczki';

- naroušitel 'człowiek przemieszczajacy się w czasie koronawirusa w miejscach publicznych bez maseczki’ (gra słowna: rušit i rouška).

Wśród analizowanych neologizmów spotykamy się również z polisemia, por:: rouškar̆ - wyraz derywowany mający w języku czeskim współcześnie aż cztery znaczenia. 1. 'producent domowych maseczek', 2. 'człowiek noszacy maseczki' - przeciwieństwo bezrouškař, 3. 'pracownik wyznaczony do pilnowania, czy ludzie/klienci zakładaja maseczki (np. przy wejściu do sklepu)', 4. 'orędownik noszenia maseczek jako ważnego działania w trakcie walki zwalczającej epidemię koronawirusową' - antonim antirouškař .

Są to słowa nazywające nowe desygnaty, nowe artefakty lub nowe czynności, ewentualnie dotyczą innowacyjnych znaczeń wykonawców czynności. Podczas ostatniego roku w codziennej komunikacji językowej zdecydowanie wzrosła frekwencja czeskiego słowa rouška ${ }^{11}$.

\footnotetext{
${ }^{11}$ Opisywana maseczka (czes. rouška) jest wytworem prac ludzkich, a noszona na twarzy chroni nas i jednocześnie nam przeszkadza (w oddychaniu i również
} 
W trakcie epidemii koronawirusowej powstały liczne słowa na podstawie sytuacji, jaka z dużą intensywnością nieubłagalnie rozwijała się na świecie. Również język czeski natychymiast zareagował na zmiany, które oddziaływały na życie obywateli. Istnieją zwroty, w których niebezpośrednio zostało wyprofilowane słowo korona. Chodzi np. o frazem: vyjít někde/někam na Adama. Wcześniej zwrot ten oznaczał 'wyjść gdzieś bez ubrania'. Współcześnie ta forma została przeniesiona na człowieka żyjącego w pandemii i oznacza: 'przyjść gdzieś bez maseczki'. Widoczna jest tutaj gra słowna: bez ubrania vs. bez maseczki, tzn. bez ubrania na twarz; zmienił się stanowczo pogląd człowieka na kwestie, co trzeba obowiązkowo ubrać, wychodząc na zewnątrz.

Opisując powstające we współczesnym języku neologizmy czy neosemantyzmy, dochodzimy do wniosku, że w niektórych przypadkach ewidentnie wzbogacają one zasób słownictwa, nawet $\mathrm{w}$ formie dubletywnej. Jako przykład można tu przywołać dwa warianty czeskiego wyrażenia: koronasádlo i korosádlo 'przyrost podskórnego tłuszczu w czasie kwarantanny koronawirusowej spowodowany zmniejszeniem ruchu'. Powstają również tzw. efemerydy typu pol. koronalia $^{12}$ 'zamiennik studenckich juwenaliów, które nie mogły odbyć się ze względu na epidemię koronawirusa’ czy właśnie przy-

komunikowaniu/mówieniu). Jest ona - jak wiele jej użytkowni- ków stwierdza symbolem codziennej uciążliwości współczesnych czasów, w jakich przyszło nam żyć.

${ }^{12}$ P i erwsza grupa dotyczy zagadnień ewentualnej stabilizacji badanych złożeń leksykalnych. Następnie można wymienić drugą g r u pę, np. composita. Występują tutaj nazwy, które pojawiają się szczególnie często podczas określonej czasowo izolacji społecznej, narzuconej odgórnie przez państwo, np.: czes. koronadovolená a koronamaturita [dosł. koronaurlop i koronamatura]. Zarówno użytkownicy języka czeskiego, jak i polskiego za pomocą wielu neologizmów nazywali elementy nowej rzeczywistości społecznej, por. np. koronachaos. Leksem ten „oswajali” lub „prześmiewali” (por. czes. koronapohádka - pol. koronabajka) czy określali nawet swoje stany emocjonalne (czes. koronaidiot - pol. koronaświrus, czes. koronadeprese - pol. koronadepresja). O ile w przyszłości nie dojdzie do ponownego „zamknięcia kraju” - jak podkreśla Agnieszka Cierpich-Kozieł (2020) - wołane czeskie koronasádlo, które - jak zaznacza Marek Łaziński (por. https://cwid.uw.edu.pl/wplyw-pandemii-koronawirusa-na-jezyk) - w języku polskim można by nazwać koronabrzuch. Widzimy jednak w nich inne profilowanie w procesie translatologicznym.

W języku polskim, kiedy zostały zamknięte szkoły i rozpoczęto tzw. ,edukację zastępczą”, najpierw pojawiły się określenia edukacja on-line, później pojawiła się forma edukacja na odległość, która przekształciła się w edukację zdalna. W języku czeskim w obiegu było najpierw vzdělávání/vyučování on-line, następnie vzdělávání/vyučování na vzdálenost, aż w końcu przyjęło się zapożyczenie (konstrukcja przymiotnikowo-rzeczownikowa) distanční vzdélávání/vyučování/výuka.

Podobnie sytuacja przedstawia się w związku składniowym pochodzącym z języka angielskiego social distancing, pol. dystans społeczny, czes. společenský odstup/rozestup ${ }^{13}$. W języku czeskim obserwujemy rodzime słownictwo odstup w znaczeniu 'odstęp', a nie przejęty leksem dystans.

\section{Zakończenie}

Jednym z zasadniczych celów niniejszego artykułu było zarówno przedstawienie nowych złożeń leksykalnych z bazowym członem $k o-$ rona-, jak i omówienie ich statusu formalnego z możliwością popogrupowania analizowanych neologizmów z uwzględnieniem realiów życia społecznego, gospodarczego, politycznego i kulturalnego,

wiele tego typu jednostek nie wejdzie na stałe do obiegu językowego. $\mathrm{Z}$ kolei na stabilizacje może mieć szansę gr u p a tr z e c i a - obejmująca słowa, które przypuszczalnie zapiszą się na kartach światowej historii gospodarczej czy politycznej, np. czes. koronakrize - pol. koronakryzys czy czes. koronadiktatura - pol. koronadyktatura.

${ }^{13} \mathrm{~W}$ języku czeskim istnieje dobrze rozpropagowane hasło, propagujące zwalczanie koronawirusa. Polega ono na powtarzaniu trzech kluczowych słów, rozpoczynajacych się w języku czeskim na literę $r$, czyli: třikrát r: rouška-rukavice-rozestup (pol. maseczka - rękawice - dystans). 
do których się odnoszą w związku z trwającą już od ponad roku epidemią COVID-19.

Język cały czas się zmienia i dostosowuje się do aktualnej sytuacji. Na podstawie wyżej przytoczonych przykładów można stwierdzić, że do codziennego słownika języka czeskiego weszły takie słowa, jak pandemie, koronavirus, distanční výuka, rouška, lockdown, karanté$n a$, vir, epidémie. Wyrazy te stosowane są przez wszystkich uczestników komunikacji językowej, czyli od najmłodszego przedszkolaka aż po emeryta seniora. Używane wyrażenia są przez wszystkich właściwie rozumiane i dobrze znane jest im ich znaczenie. Niektóre z tych nowo powstałych nazw przeżywają prawdziwy renesans ze względu na zdecydowanie większą frekwencję (przesunęły się z peryferii w kierunku centrum języka) w porównaniu np. z takimi jak: služba E.ONzdravi (pol. e-zdrowie); eRecept ${ }^{14}$ (pol. e-recepta); e-shop/e-obchody (pol. e-sklepy/internetowe sklepy), zdravi online (pol. e-zdrowie), telefonické konzultace a telefonické sdělováni výsledkư (pol. teleporady) itp.

\section{Literatura}

C i e r p i ch-K o z i eł Agnieszka, 2020, Koronarzeczywistość - o nowych złożeniach z członem korona- $w$ dobie pandemii, ,Język Polski” (100), $\mathrm{nr} 4$ s. 102-117. Online: https://jezyk-polski.pl/wp-content/uploads/2020/09/ Artyku182-Cierpich-Koziel.pdf.

Jan ow ska Aleksandra, Niewiara Aleksandra, 2001, Szkolny stownik terminów gramatycznych, Katowice: Wydawnictwo Videograf II.

K r a u s Jiř́i a kol.,2007, Nový akademickýslovník cizich slov A-Ž, Praha: Academia.

L o t k o Edvard, 2003, Slovnik lingvistických terminů pro filology, Olomouc: Vydavatelství Univerzita Palackého.

M a r t i n c o vá Olga a kol., 1998, Nová slova v češtině. Slovník neologizmů. Díl 1 Praha: Academia.

${ }^{14}$ Lékařem vystavený eRecept je uložen do tzv. Centrálního úložiště elektronických receptů (CÚER) - pol. wystawiona e-recepta przez lekarza jest zdeponowana w tzw. Centralnym Rejestrze Recept Elektronicznych. Uwaga także na zmianę rodzaju gramatycznego: w języku czeskim jest rodzaj męski e-recept, a w języku polskim mamy do czynienia $\mathrm{z}$ rodzajem żeńskim e-recepta.
M a rt in c o vá Olga a kol., 2004, Nová slova v češtině. Slovník neologizmů. Díl 2 , Praha: Academia.

M r a v i n a c o v á Jitka, 2005, Neosémantizmy vzniklé pod vlivem cizího jazyka, [w:] Neologizmy v dnešní češtině, red. O. Martincová, A. Rangelova, J. Světlá, Praha: Vydavatelství Academie věd České republiky, Ústav pro jazyk český, s. $180-186$.

Pravidla českého pravopisu, školní vydání včetně dodatku, 1999, Praha: Vydavatelství Ústavu pro jazyk český Č́R, Nakladatelství Fortuna.

$\mathrm{R}$ a $\mathrm{n}$ g $1 \mathrm{ov}$ a Albena, 2005, Neosémantizmy a neosémantizační procesy, [w:] Neologizmy v dnešní češtině, red. O. Martincová, A. Rangelova, J. Světlá, Praha: Akademie věd České republiky, Ústav pro jazyk český, s. 159-179.

S v o b od o vá Diana, 2009, Aspekty hodnoceni cizojazyčných přejímek: mezi módností a standardem, Ostrava: Vydavatelství Ostravské univerzity.

\section{Netografia}

file://C:/Users/DOM/AppData/Local/Temp/Koronak neni_kamarad.pdf

https://cesky.radio.cz/kovidek-rousicky-rouskomando-koronavirus-obohatil-cestinu $-8103372$

https://cestina20.cz/slovnik

https://ct24.ceskatelevize.cz/veda/3071100-koronavirus-meni-cestinu-vznikly-uzstovky-novych-slov-popisuji-lingviste

https://cwid.uw.edu.pl/wplyw-pandemii-koronawirusa-na-jezyk/

https://edukacja.dziennik.pl/aktualnosci/artykuly/7737856,koronawirus-profesorbralczyk-nowe-slowa.htm

https://www.idnes.cz/zpravy/domaci/koronavirus-koronakrize-korontena-koronacneologismy-vedkyne-liskova.A200403 095610 domaci remy

https://cestina20.cz/slovnik/ oraz Český národní korpus https://www.korpus.cz/slovo-v-kostce/search/cs/koronavirus

https://www.lidovky.cz/domov/koronaut-rouskomil-ci-netkafe-epidemie-korona viru-meni-v-cesku-slovnik-pribyly-stovky-slov.A200429 203142 ln domov ele

http://www.neologismy.cz/index.php?retezec=korona*\&nove hledani=1\&prijimam $=1$

https://www.novinky.cz/koktejl/clanek/prymulant-ci-domahnij-pandemie-meni-cestinu-40349463

https://program.rozhlas.cz/cestina-za-casu-koronaviru-8180505 